\title{
China introduces the 24-hour rule
}

\author{
Bergami Roberto \\ (School of Economics and Finance, Centre for International Corporate Governance Research, \\ Victoria University, Melbourne 8001, Australia)
}

\begin{abstract}
Recently, international movement of cargo had been the subject of increasing border control measures that may be causing tension between the needs for security and the needs for trade facilitations. On the one hand customs authorities are charged with the responsibility for policing a country's borders, and consequently they need to have in place measures to ensure that only legitimate trade takes place and that this trade does not present security concerns. On the other hand we have the requirements of traders, who benefit from an environment of trade facilitation with speedy and efficient movement of cargo across international borders, with minimal bureaucratic intervention. This paper focuses on and provides early discussion and comments on the possible ramifications of the introduction of the 24-hour rule in China, effective for all exports and imports of sea freight container traffic since January 1, 2009. The new rules will have significant impact on the logistics flows of exporters and importers alike. Specifically, the reporting requirements timelines are likely to result in increased costs in cargo processing at wharves that traders will have to bear; place added pressure on storage facilities at wharves, or at container depots; and may additionally increase the amount of inventory buffer because of the timing of the data reporting requirements. The paper concludes that security needs have prevailed over trade facilitation considerations and that traders should urgently implement a review of existing practices to ensure they comply with the China Customs requirements, whilst simultaneously minimizing cost increases.
\end{abstract}

Key words: 24-hour rule; cargo security; anti-terrorism; international regulations; China Customs

\section{Introduction}

The movement of cargo since the events of 9/11 has been subjected to much focus and security attention, from all border control agencies around the world. The heightened awareness that aircrafts and ships may be used as weapons of mass destruction for terrorist activities has caused a shift in the way cargo movements are regarded, and the advent of technology has provided additional tools for risk management applications. It is important to note that the use of electronic applications for customs control and operations was foreshadowed nearly two decades ago, and embodied in the 1999 revision of the Kyoto convention. This convention, inter alia, sets the framework for electronic data submission to customs authorities, a core component of the 24-hour rule, the subject of discussion in this paper.

Further to the Kyoto convention, a number of initiatives, designed to enhance the security of the supply chain, have also been pursued, largely driven by a US Government Administration influenced by the events of 9/11. An example is the World Customs Organization's (WCO) "SAFE Framework of Standards” (Danet, M., 2007), designed to secure and facilitate global trade. This project began with the formation of a Joint Customs-Industry Task Force on

Bergami Roberto, senior lecturer, School of Economics and Finance, Centre for International Corporate Governance Research, Victoria University; research fields: government regulations, delivery terms (Incoterms), international payment terms and market entry barriers. 
Security and Facilitation in 2002 (Tweedle, D., 2008), following an earlier Container Security Initiative proposal in 2001. The WCO claims that, "Customs can and should play a central role in the security and facilitation of global trade ... to optimize the securing of the international trade supply chain while ensuring continued improvements in trade facilitation. Customs should ... develop co-operative arrangements with other government agencies. It is an unacceptable and an unnecessary burden to inspect every shipment. In fact, doing so would bring global trade to a halt ... modernized customs administrations ... should not burden the international trade community with different sets of requirements to secure and facilitate commerce ... there should be one set of international Customs standards ... that do not duplicate or contradict other intergovernmental requirements” (Danet, M., 2007).

US Customs and Border Protection (CBP) were the first agency to implement measures, on a global scale, that followed the principles of what is now the SAFE framework, through the implementation of the 24-hour rule for all sea freight container import consignments destined, or transiting through the US, effective on February 2, 2003. The reason for the focus on container traffic is that about $90 \%$ of world trade is estimated to be transported in sea freight containers. However, to date, a significant number of countries have not imposed their own 24-hour rule requirements. Not surprisingly, probably due to their membership of NAFTA, Canada and Mexico have followed the lead of the USA, but this is not the case for the EU: Plans by the European Union to tighten container security through a scheme modeled on one already operational in the US are falling behind schedule, partly because of the difficulty of obtaining uniformity across member states (Tran, D., 2008).

It would not be difficult to imagine the chaos created within the $27 \mathrm{EU}$ member states if there was a lack of uniformity in the implementation of an EU-wide 24-hour rule policy.

In the case of China, the implementation of a container security initiative, similar to that of the US, has been under consideration since at least 2006, when the WCO met in Urumqi. It was acknowledged at that meeting that considerable resources would need to be devoted to this project, and this probably explains the time frame for implementation. The official announcement of the 24-hour rule indicates a much wider application to international trade flows than other countries so far, because in the case of China Customs, the 24-hour rule applies not only to imports, but also exports. Some of the major practical implications resulting from this announcement are discussed in the paper. It should be noted that because the implementation of these rules, at the time of writing, is less than two months old, a body of literature specific to this issue has not yet developed, consequently a literature review is not provided here, but where applicable, use of existing literature that broadly relates to the issues discussed has been incorporated into the paper. It should also be noted that the words, seller and exporter are used interchangeably, as are the words buyer and importer, and the paper should be read as being gender neutral.

\section{China Customs and the 24-hour rule: Import and export cargo requirements}

Decree No. 172 "Measure for Manifest Information Administration for Inbound and Outbound Means of Transportation" (referred as "decree") was adopted by the Minister of General Administration of Customs in China, released on March 28, 2008, with an effective date on January 1, 2009. The new requirements, have caused concern among the logistics community, and have been described as "a rule that not only copies, but outdoes US cargo security policies” (Thai Shipper, 2009). This is because export as well as import cargo is affected by the rule in China, whereas in the US the 24-hour rule applies only to import cargo.

The shipping and logistics industries have been quick to announce the 24-hour Chinese rule requirements to their customer base via internet announcements, or through their regular newsletters. A number of industry based 
journals, such as American Shipper and Transport Weekly, have communicated these requirements to their readership via the internet. The trading community cannot therefore claim ignorance about the new rules before their effective date. However it is one thing to know about the rules and quite another to make the necessary business processes changes to accommodate the new requirements and be complaint, especially as the penalties, discussed later in the paper, are significant indeed. In order to appreciate the required changes introduced by the Chinese 24-hour rule, the import and export requirements are discussed next.

Chinese importers are subject to a similar set of requirements that US importers have been subjected to since 2003 when the CPB introduced the US 24-hour rule. China Customs 24-hour rule applies to all modes of transport, that is sea, air, road and rail, and the relevant operators will need to provide advance manifest information to China Customs electronically. Apparently the rule does not apply to shipments imported into Hong Kong and Macau (OOCL, 2008). It should be noted that discussion of the China Customs 24-hour rule is limited to sea freight consignments only.

The Chinese 24-hour rule requires certain parties intending to transport goods to China to submit advance manifest details to Chinese Customs 24 hours before the container is loaded on a ship anywhere in the world. Under no circumstances will the carrier be allowed to load cargo on board if manifest filing is rejected by Chinese Customs (Transport Weekly, 2008).

The manifest includes the original manifest, pre-stowage manifest and load (boarding) manifest, as per Article 2 of the decree, and it is expected that manifest information include details of the Master Bill of Lading (MBL), or waybill and the House Bill (HB) or waybill under it. This information is routinely available, but it is the issue of timely information availability that becomes a challenge.

In accordance with the decree, Article 4: Parties who have the obligation to transmit electronic manifest data (hereinafter referred to as "manifest transmission parties") including operators of inbound and outbound transportation vehicles, non-vessel operating common carrier (NVOCC), freight forwarders, shipping agency companies, postal enterprises and express delivery operators, should transmit electronic manifest data to the Customs within the set time limit in accordance with the scope of customs registration.

It should be noted that importers and exporters do not fall into the above categories, although they become separately involved in the customs clearance process in their respective countries at a separate stage. "Parties submitting data must first register with China Customs” (Johnson, E. \& Kulisch, E., 2008), and these requirements are detailed in Article 7 of the Decree. There is no evidence to suggest that this is a particularly troublesome process.

There are two types of data elements that require to be submitted in advance to China Customs:

(1) Main: to be submitted to customs by the carrier 24 hours prior to loading; and

(2) Other: to be submitted before the vessel arrives at its destination.

These are categorized as "mandatory" and "conditional" data elements. Mandatory data elements are the main data elements plus other elements that have to be submitted for all consignments, that is the minimum standard of data declaration. Conditional elements are those that apply only in specific circumstances, such as transhipment, or dangerous goods. Typical data elements requirements include:

\footnotetext{
$\cdot$ Vessel/Voyage

- Port of Discharge

- Payment Terms

- Package Type and No of Packages.
} 


\section{- Gross Weight}

- Container No. and seal

- Goods description.

These requirements will necessitate process flow changes and a degree of co-operation between all the parties involved in the transaction to make sure that China Customs requirements are met, otherwise a "Do not load" notification will be issued and the container will remain at the port of export, while the ship sails on to its next destination. Under these circumstances, the exporter may be facing additional charges because, at least:

- The missed sailing date will result in cargo delays, with consequential downstream effects on the buyer's business;

- The goods will need to be removed from the export wharf and taken to another storage area;

- The consignment will need to be booked again and the whole process begins anew, presuming buyer demand continues; and

- The cash flow implications that the exporter will experience as a result of delayed deliver- the later the delivery, the later the payment. Additionally, if we consider a Letter of Credit transaction, where payment is typically connected to meeting shipping dates, late shipment will lead to additional financial losses, quite separate to those accruing on the movement of the cargo.

From a customs clearance point of view, the process should run smoothly, as long as the buyer does not elect to transact on a delivery term of Incoterms 2000 Ex Works (EXW) basis. EXW requires the buyer to collect the goods from the agreed premises (usually the seller's warehouse) and undertake the export customs clearance task, in the country of despatch - this typically involves the use of third party providers. Depending on the country involved the clearance process may be quite difficult, producing information delays that may fail to satisfy the China Customs 24-hour rule, and consequently miss sailing dates. Other Incoterms 2000 that place the obligation for customs clearance, and contracting for the carriage of goods, on the exporter, may provide a better alternative for the Chinese buyer. These terms are: Cost and Freight (CFR); Cost Insurance and Freight (CIF); Carriage Paid To (CPT); Carriage and Insurance Paid to (CIP); Delivered Ex Ship (DES); Delivered Ex Quay (DEQ); Delivered Duty Unpaid (DU); and Delivered Duty Paid (DDP). Where the responsibility falls on the exporter to arrange for the carriage of the goods it should become implicit that the requirements of the decree will be satisfied. As a risk management tool, the Chinese buyer may consider specifically addressing compliance with the decree in the commercial contract.

From the carrier's point the requirements of the decree will add costs to their processes, and these costs will be recouped through increased fees, both on import and exports, although "measuring the impact of security programs is problematic, given the evolving nature of these initiatives” (Bagai, S. \& Wilson, J. S., 2006). It has been estimated that for the USA, the "potential burden imposed on carriers by 24-hour the rule is approximately USD 281.7 million” (Crist, P., 2003) per annum. This figure was calculated using a USD 25 fee per container and based on import flows only, as the US 24-hour rule does not currently apply to exports. This figure does appear to be generously calculated, as shipping lines practices, according to industry sources, are to charge on a 'per consignment' (transport document - Bill of Lading) basis, not on a 'per container' basis. Estimates on inward and outward flows of container traffic for 2007 at main Chinese ports, suggest that the total number of containers is somewhere between 83 million (Drewry Shipping Consultants) and 91 million (Figures obtain from Port of Hamburg internet set) containers. Industry sources estimate that at this stage no additional charges are being levied to comply with China Customs 24-hour rule, as it would appear that a six-moth transition period has been 
informally agreed to (Rajesh J., 2009), and no penalties will apply until the beginning of July 2009. It is believed that once the rule is rigidly enforced, fess will be introduced, but at a much lower rate than the estimates quoted above, suggesting something akin to USD 5 per consignment. It is not possible to conclusively arrive at a cost per consignment, simply because the number of Bills of Lading issued is not known. As a rough guide, industry sources estimate that the overall average number of containers per Bill of Lading is somewhere between 4 and 8 . If the presumed USD 5 fee per Bill of Lading is accepted alongside the average number of containers per Bill of Lading, then the cost of compliance with the China Customs 24-hour rule is estimated to average somewhere between a significant USD 54.375 million and USD 108.75 million per annum, as shown in Table 1.

Table 1 China Customs 24-hour rules-Estimated additional costs

\begin{tabular}{cccc}
\hline $\begin{array}{c}\text { Number of containers } \\
\text { per Bill of Lading issued }\end{array}$ & Number of Bills of Lading issued (million)* & $\begin{array}{c}\text { Bill of } \\
\text { Lading fee USD }\end{array}$ & $\begin{array}{c}\text { Total cost } \\
\text { USD million }\end{array}$ \\
\hline 4 & 21.75 & 5 & 108.75 \\
8 & 10.875 & 5 & 54.375
\end{tabular}

Note: * This figure has been calculated by the average container movements $[(83+91) / 2]=87$ million divided by either 4 or 8 containers per Bill of Lading issued.

The estimates above do not include the additional costs that traders may have to bear as result of changed processes and timelines. The impact of providing information in advance is not insignificant. Fig. 1 shows the effect on the timelines of the introduction of the US 24-hour rule.

Typical Container Booking/Bill of Lading Cycle: before 24-hour advance notification

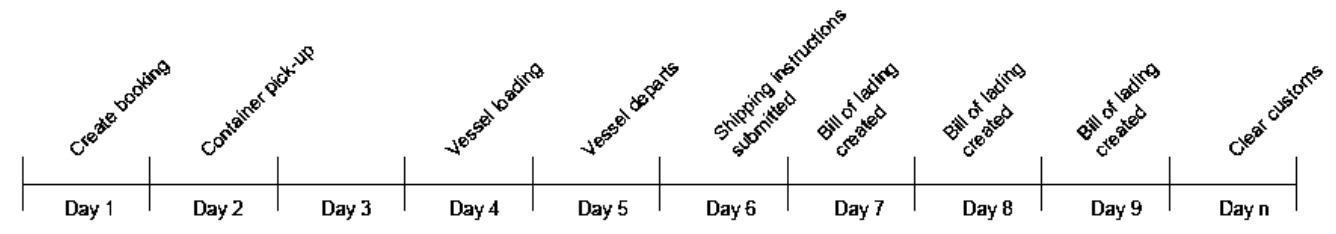

Typical Container Booking/Bill of Lading Cycle: after 24-hour advance notification

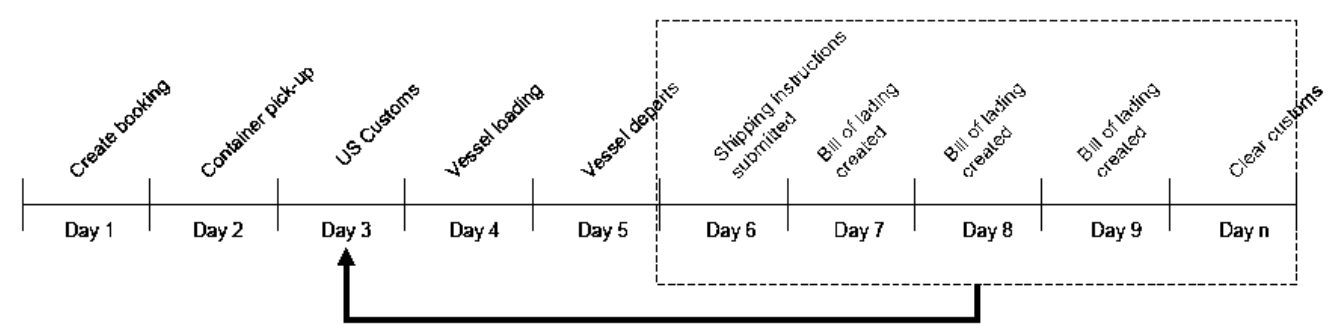

Fig. 1 Timing impact of the 24-hour rule

Data source: Crist, P. (2003). Security in maritime transport: Risk factors and economic impact. Maritime Transport Committee, OECD, Paris, France.

Given that the China Customs 24-hour rule closely follows the model of the US regulations, it can be reasonably expected that the same situation will develop, however the impact will be greater in the case of the China 24-hour rule, because this applies to exports as well. Indeed, there are early signs that the process flow are already subject to change, and that shipping lines are demanding earlier information to comply with China Customs requirements: Please note that in order to process your cargo information with China Customs before cargo loading, 
your shipping instruction must be received at least 2 working days prior to the cargo load port cutoff (OOCL, 2009).

The impact of this requirement is that exporters will need to begin the despatch process ahead of time, and ultimately that will have a negative impact of just in time systems, as "to avoid delays and fines shippers are adding extra cycle time to their supply chain” (Bagai, S. \& Wilson, J. S., 2006), but this is counter effective, as in an environment of "just-in-time" manufacturing, outsourcing and global production sharing, firms cannot afford delays with complex and inefficient customs rules, lack of modern systems of information technology applied in maritime transport, and other areas of trade facilitation. Identification of bottlenecks - administrative, regulatory, or infrastructure related - can better equip ... countries to compete in international markets for goods. Inefficient and unnecessary import and export procedures impede trade flows. Reducing trade-related transaction costs can expand trade (Bagai, S. \& Wilson, J. S., 2006).

We can therefore note that the implementation of these rules impact both sellers and buyers. According to Walkenhorst and Dihel (2002), cited by Bagai and Wilson (2006), strengthened security systems lead to increased "frictional costs relating to transport, handling, insurance and customs ... [causing] ... world welfare to decline by $\$ 75$ billion per year as a result of a $1 \%$ ad valorem increase in frictional costs to trade”.

However, Hertel, Walmsley and Ikatura (2001), cited by Bagai and Wilson (2006) claim there are positive longer term gains from streamlined barrier clearance processes, as automated customs can lower the direct costs of customs clearance by the equivalent of 0.2 percent of the value of traded goods. By accounting for the indirect benefits of reduced delays, costs are reduced by 1 percent of merchandise value (Bagai, S. \& Wilson, J. S., 2006).

In the case of the 24-hour rule, these claims may be, at least, partially rejected because whilst on the one hand automated processes provide efficiency gains through improved data transmission and, reduction in transposition errors, the delays to just-in-time systems far outweigh any gains.

Non-compliance with the China Customs 24-hour rule can be severe, as breaches will be punished in accordance with the Customs Law and Regulation of the People's Republic of China on the implementation of Customs Administrative Punishment. Those constituting crimes will be dealt with in accordance with Criminal Law (Yaoh, D. H. \& Tsui, C., 2008).

Shipping lines appear to have reached consensus on not being willing to load any container on a ship unless clearance form China Customs has been properly received. The financial cost of rectifying any mistakes, quite apart form the penalties incurred, would be significant and may jeopardise the complete flow of loading/unloading episode with consequential downstream effects in shipping delays.

\section{Conclusion}

The introduction of the China Customs 24-hour rule is a ground-breaking initiative as it applies to both import and export flows. Indeed, it is the first time anywhere in the world that such a customs initiative has encompassed the export trading community.

Border policing functions by necessity must have some focus on security measures, to ensure that legitimate and safe trade is conducted among countries, and in order to do so, existing processes must change to accommodate the new requirements. It is generally accepted that there is a fine balance between trade facilitation and border security, and tensions occur where there are competing priorities. The China Customs 24-hour rule is an extension of the already existing US requirements, and this evidences another step towards a common world standard and approach in securing the supply chain. 
The data elements required are not something new, that is, they have always existed ... somewhere in the system. The extraction and timely availability of data is the primary challenge faced by all concerned, and in order to be compliant, cargo handling and forwarding clearly needs to change. For exporters, importers and logistics providers, there is little choice but to review existing processes and contractual arrangements, and try to optimize the supply chain within the constraints of the new rules. That these processes are difficult is perhaps evidenced by the fact the barely one week after the effective date of the rules, a transition period was declared, giving the trading and shipping communities a little more time to become compliant.

It will be interesting to observe whether China Customs will, in the future, follow the lead of the US and extend the 24-hour rule further, to the equivalent of the 10+2 rule, by asking for additional data elements in the pre-loading notification. If this were to be the case, another round of business process reviews and changes in contractual arrangements would surely be required, and this would come at an additional cost.

\section{References:}

Bagai, S. \& Wilson, J. S. (2006). The data chase: What's out there on trade costs and nontariff barriers? World Bank Policy Research Working Paper (Document No. WPS3899).

China to implement 24-hr advance manifest rule. (2008). Transport Weekly, (31). Retrieved November 5, 2008, from: http://www. transportweekly.com/pages/en/news/articles/55441/.

Crist, P. (2003). Security in maritime transport: Risk factors and economic impact. Maritime Transport Committee, OECD, Paris, France.

Danet, M. (2007, June). SAFE framework of standards. Brussels: World Customs Organization.

Department of Homeland Security. (2003, January 30). Enforcement of 24-hour rule begins February 2. Retrieved October 26, 2008, from: http://www.cbp.gov/xp/cgov/newsroom/news_releases/archives/cbp_press_releases/012003/01302003.xml.

Drewry Shipping Consultants, personal communication.

Johnson, E. \& Kulisch, E. (2008, December 31 ). New China advanced manifest rules effective Jan. 1. American Shipper, Shipper’s Newswire.

Kyoto Convention. (1999). International convention on the simplification and harmonization of customs procedures (as amended). Retrieved October 29, 2008, from: http://www.wcoomd.org/kybodycontent.htm.

Minister of General Administration of Customs. (2008). Decree No. 172 of general administration of customs.

Five Star Shipping and Agency Company Pty Ltd. (2008). Notice to shippers: China customs 24 hour rule. Retrieved January 14, 2009, from: http://www.fivestarshipping.com.au/pdf/China_R24.pdf.

OOCL. (2008). China's 24 hour advanced manifest regulation - Data elements, customer advisories, October 28. Retrieved January 22, 2009, from: http://www.oocl.com/eng/resourcecenter/customeradvisories/china24hradvancemanifestrule/28oct2008.htm.

OOCL. (2009). China's 24 hour advanced manifest regulation - Implementation of manifest submission for import shipments to China, customer advisories. Retrieved January 15, 2009, from: http://www.oocl.com/eng/resourcecenter/customeradvisories /china24hradvancemanifestrule/2009/2jan2009.htm.

Rajesh J. (2009). China allows grace period on 24-hour rule, Lloyd's list, container section. Retrieved January 22, 2009, from: http://www.lloydslist.com/ll/news/china-allows-grace-period-on-24-hour-rule/20017604764.htm.

South African Revenue Service. (2002). Container security. Retrieved November 5, 2008, from: http://www.sars.gov.za/home. asp? pid $=561$.

Tweedle, D. (2008). Logistics, security and compliance: The part to be played by Authorized Economic Operators (AEOs) and data management. World Customs Journal, 2(1), 101-105.

Tran, D. (2008). Brussels’ postpones’ start of 24-hour container regulations. The Vietnam Maritime Social Network. Retrieved January 27, 2009, from: http://www.vinamaso.net/news-events/rules-regulations/brussels-postpones-start-of-24-hour-container-regulations.html.

Thai Shipper. (2009). China relents on copycat 24-hour manifest filing rule. Retrieved January 22, 2009, from: http://www. thaishipper. com/Content/Content.asp?ID=25817, accessed.

World Customs Organization. (2006). Executive Summary, Seminar on WCO Framework of Standards and Customs Data Model, 12-14 July, Urumqi, People's Republic of China. Retrieved October 26, 2008, from: http://www.adb. org/Documents/ Events/2006/WCO-FSCDM /executive-summary.pdf.

Yaoh, D. H. \& Tsui, C. (2008). PRC advance manifest rule scheduled to be effective January 1, 2009. Risk Management Update Transportation, Risk Management Insurance Brokerage Limited, December. Retrieved January 15, 2009, from: http://www. riskmgtgroup. com/Doc/RMU-Dec-2008.pdf.

(Edited by Emily and Ann) 